\title{
Past climate changes and human adaptation
}

\author{
Rui Pena dos Reis', M.H. Henriques ${ }^{1}$, L. Oosterbeek², E.I. Alves ${ }^{3}$, \\ P. Rosina ${ }^{2}$, G.G. Garcia' and P. João ${ }^{4}$ \\ International Meeting on Paleoclimate, Coimbra, Portugal, 18-19 June 2019
}

\begin{abstract}
Climate is the planetary response of the atmospheric circulation to changes in its composition, the solar system configuration, Earth's rotation, and the distribution of the oceans and continents. As a result, it is continuously evolving, expressed at a global scale by subsiding and uplifting convection cells. These changes have long been recognized and documented in geologic objects of all ages. There are climate signals in many rocks, different geologic features, fossil fragments and imprints, prehistoric remains, and historical reports that can be analyzed and interpreted in order to learn more about past climate changes. Lessons from the past support the view that change is the rule, not the exception, as evidenced by strongly contrasting and chaotic extremes, defined by the whole ensemble of extra-planetary, external, and internal geodynamic controls.
\end{abstract}

Science-based knowledge is crucial to address current challenges, and this played a major role in the organization of the PAGES-endorsed International Meeting on Paleoclimate: Change and Adaptation (pastglobalchanges.org/ calendar/2019/127-pages/1920). This event was organized by two research and development centers at the University of Coimbra (the Geosciences Center and the Center for Earth and Space Research) within the framework of two UNESCO Chairs (Geoparks, Sustainable Regional Development and Healthy Lifestyles, and Humanities and Cultural Integrated Landscape Management; en.unesco.org/ unitwin-unesco-chairs-programme).

The conference was attended by 133 participants from 19 nations, including 64 researchers and 69 students. A total of 69 papers were presented and published in a special online volume (uc.pt/ fctuc/ID/Geo/DOWNLOAD_DOCUMENTS/ AREADOMENIU8). The meeting also included a fieldtrip to the Aspiring Estrela Geopark, where the landscapes formed during the Last Glacial Maximum are particularly well exposed (Fig. 1).

The organizers and participants took an observational approach in the presentations and open discussion on paleoclimatic signals designed to improve our look at the present and to ground future perspectives. The discussion focused primarily on three different topics, including paleoclimates in the solar system: external forcing; climate record in geological time: lessons to learn; and climate events and human adaptations throughout the Quaternary.
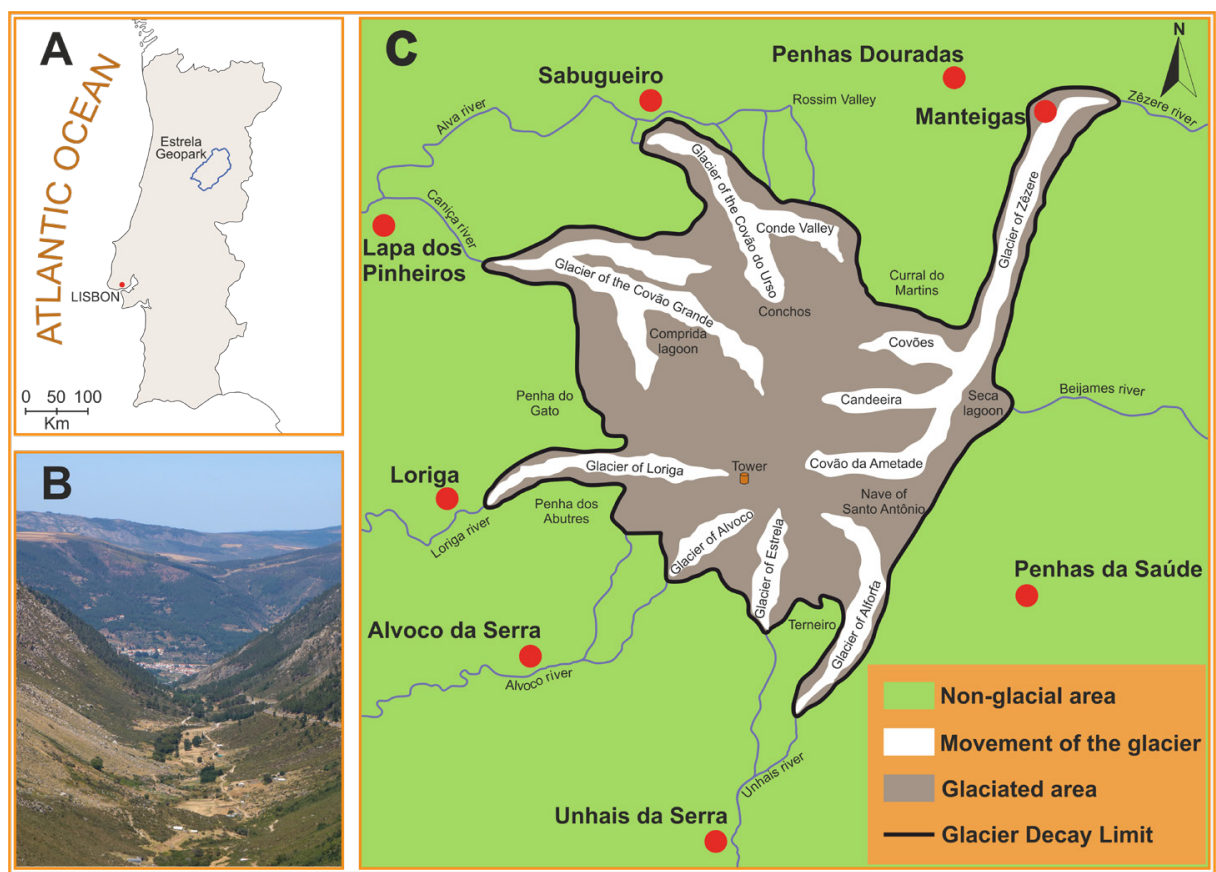

Figure 1: (A) Location map of the Aspiring Estrela Geopark (Portugal); (B) Zêzere glacial valley (Photo Credit: Aspiring Estrela Geopark); (C) Schematic paleogeographic model of glacier surface of the Estrela plateau icefield during the last maximum of the glaciation of the Serra da Estrela.
Polar climate and prehistorical climate signals, as well as planetary climate science, were the subjects of four complementary keynote presentations: climatic catastrophes in the solar system by David Grinspoon, animal extinctions and climate change in the Quaternary period by François Djindjian, the record of Holocene environmental changes in polar and mountain ice cores by Jefferson Simões, and early Holocene paleohydrological and sedimentary indices from the alluvial archives of the Middle Moulouya (the Ait Blal sequence, Morocco) by Larbi Boudad.

Contributions on the Quaternary gave evidence supporting the importance of focusing on adaptive strategies of humans in the past allowing them to overcome often fast climatic oscillations. This enabled early humans both to cope with extreme dry and cold conditions in several moments throughout the Pleistocene as well as to design innovative strategies, including advances in farming techniques, as a response to the 8.2 kyr event. A special session on rock art and climate change, which involved key clusters from Portugal, Spain, and France, enabled assessment of both the prehistoric art motives as indirect evidence of climate changes (through the depiction of diverse zoocenosis) and the impact of these on the conservation of the art itself. These discussions, which also engaged the UNESCO Chair on Humanities and Cultural Integrated Landscape Management, demonstrated that while human impact on the climate was negligible, humans' adaptive capacity had important impacts on the biosphere dating back to the dawn of food production.

\section{AFFILIATIONS}

${ }^{1}$ Geosciences Centre of the University of Coimbra and Department of Earth Sciences, Faculty of Sciences and Technology, University of Coimbra, Portugal ${ }^{2}$ Instituto Politécnico de Tomar; Instituto Terra e Memória; Geosciences Centre of the University of Coimbra, Portugal

${ }^{3}$ Centre for Earth and Space Research of the University of Coimbra and Department of Earth Sciences, Faculty of Sciences and Technology, University of Coimbra, Portugal

${ }^{4}$ Research Centre on Didactics and Technology in the Education of Trainers of the University of Aveiro, Portugal and Geosciences Centre of the University of Coimbra, Portugal

\section{CONTACT}

Rui Pena dos Reis: penareis@dct.uc.pt 